\title{
Contribution to the Treatment of Urban Wastewater in the City of Fez by Coagulation and Flocculation Using a Biodegradable Reagent
}

\author{
Ibtissame Elmansouri ${ }^{*}$, Amal Lahkimi², Mohamed Benaabou ${ }^{2}$, Mehdi Chaouch $^{2}$, \\ Noureddine Eloutassi ${ }^{2}$, Hicham Bekkari ${ }^{1}$ \\ 1 Laboratory of Environmental Biotechnology, Agri-food, Health Sidi Mohamed Ben Abdellah University, \\ Faculty of Science Fez, Morocco \\ 2 Laboratory of Molecular Organometallic Materials Engineering and Environment, Sidi Mohamed Ben \\ Abdellah University, Faculty of Sciences Fez, Morocco \\ * Corresponding author's email: elmansouriibtissam33@gmail.com
}

\begin{abstract}
This study includes two parts; the first one, concerns evaluation of the physicochemical and microbiological quality of the urban wastewater of the city of Fez, through a space-time dynamics. In turn, the second part deals with the contribution to the treatment of these effluents, by a new biodegradable reagent in the process of physicochemical treatment (coagulation flocculation). For this purpose, the sampling of urban wastewater was carried out 4 months (September, December, February and June 2019), at a rate of two samplings per period on 4 specific sites along the river Fez, the degree of contamination of which differs from one site to another, according to space and time. The diagnostic of these stations showed a high level of pollution that is difficult to biodegrade. Indeed, this pollution can cause negative effects not only on the environment but also on human's health. In order to take long-term action against the low quality of water and to replace certain inorganic coagulants, alternative processes for water treatment using cactus powder were set up. The characterization of results showed that the urban effluent has a high load in terms of electrical conductivity (EC), dissolved oxygen, chemical oxygen demand (COD), as well as concentrations of faecal coliforms, streptococci and staphylococci. In addition, the purifying power revealed that the removal rate of COD reaches maximum values of $38 \%$ and $58 \%$ forlimeand the mixture of lime with cactus powder, respectively.
\end{abstract}

Keywords: treatment, physicochemical, microbiological, urban water.

\section{INTRODUCTION}

Internationally, the water and sanitation sector remains poorly developed in health facilities. In Morocco, the situation of water scarcity is increasingly alarming and water stress is indeed a major concern in this country [Bennouna, 2020]. The city of Fez has experienced a very significant demographic growth, its current population increased to $1,100,000$ inhabitants and should reach 1,500,000 inhabitants in 2030 [AmartiRiffi et al., 2013]

The effluents of this city, evaluated at $110,000 \mathrm{~m}^{3} \cdot \mathrm{d}^{-1}$, are characterized [Bzioui, 2004] by a strong organic component and a considerable presence of chemical substances. This pollution constitutes 2,750,000 equivalent inhabitants of industrial effluents, $20,000 \mathrm{~m}^{3} \cdot \mathrm{d}^{-1}$ of domestic effluents, as well as $6294 \mathrm{~T} /$ year of nitrogen and $1499 \mathrm{~T} /$ year of phosphates in the case of agricultural effluents [Bzioui et al., 2004]. This has led to the suffocation of fauna and flora, and contributed to the proliferation of water-borne diseases for the riparian populations [Amarti-Riffi et al., 2013]. Faced with this precarious pollution situation, the reuse of polluted water has become crucial.

The physico-chemical and microbiological characterization of the waters of Fez river and Sebou have been the subject of several studies [Ferdaous et al., 2015]. The coagulation-flocculation process is an advanced technique because of its basic design, and its ability to remove 
toxic compounds. Utilisation of such coagulants as alum increases the operational costs of the treatment and limits the practicality of the process. Hence, the interest in using durable agents from renewable sources such as agro-industrial waste, as it is a widely available material at low cost and capable of replacing chemical agents [E1 Mouhri et al., 2021].

The cactus racket is characterized by,its attractiveness as an edible product, and its high digestibility, with a high content of water, soluble carbohydrates, ash, $\mathrm{Ca}, \mathrm{K}$ and vitamin A [El Kharrassi et al., 2015]. Cactus powder is a biomaterial with interesting adsorption capacities that can be an alternative to other commercial carriers.

The aim of this study was to conduct a spatiotemporal evaluation of the pollutant load of the urban waters of the city of Fez in order to determine the localization by the geographical information system (QGIS), and contribute to the treatment of pollutants by coagulation flocculation.

\section{MATERIALS AND METHODS}

\section{Geological and hydrological aspects of the study area}

The city of Fez, belonging to the region of Fez-Meknes, is located in a very diverse geomorphological context composed of plains, valleys, plateaus and reliefs [Mohammed et al., 2017]. It is characterized by a hydrographic system centred on the river Fez which flows from West to East of the city. It originates at the surface of Ras El Ma and drains the water table until it leaves the Saïs plain. It is fed by groundwater and receives several tributaries along its course towards the sebou river [Lalami et al., 2011] (Figure 1).

\section{Sampling sites}

Four points along the river Fez watershed were selected, from which samples were taken (Table 1) over a period of 4 months (September, December, February and June 2019) at an average rate of two times per month. The choice of sampling sites for the various water samples was made taking into account the various industrial and artisanal activities. A map of the location of the study sites was created with the QGIS software (Figure 2).

\section{Selection and description of study stations}

The choice of the sampling points for the various water samples was made taking into account the various anthropic activities identified: industrial and artisanal waste dumps; the geographical coordinates of each site were established using a GPS device.

The wastewater samples were collected using $500 \mathrm{ml}$ polyethylene bottles, previously rinsed and labeled; the measurements of temperature,

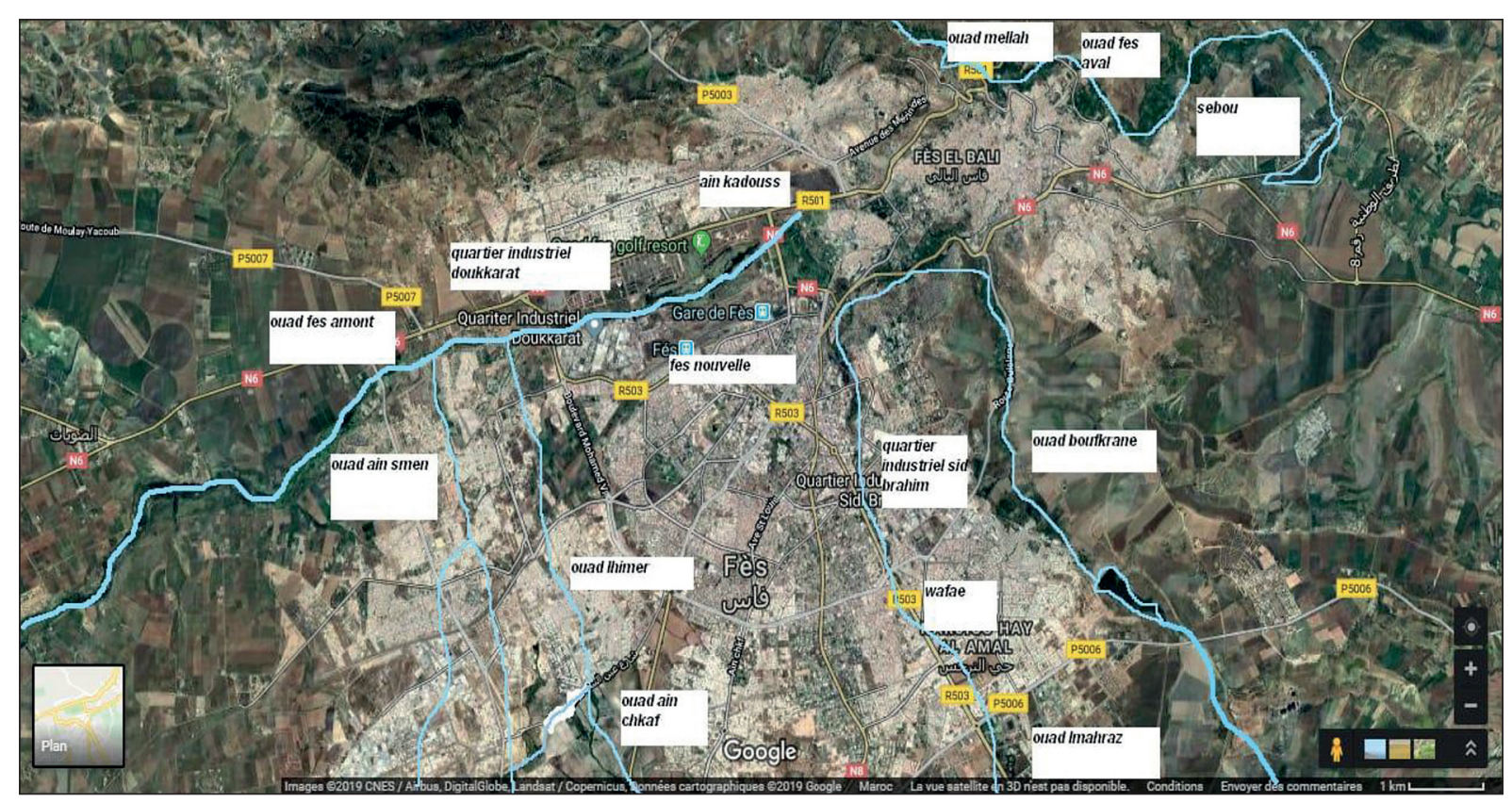

Figure 1. Hydrological view of the city of Fez [El Ouedghiri et al., 2014] 
Table 1. Coordinates of the sampled points

\begin{tabular}{|c|c|}
\hline Area & Location \\
\hline Station 1 & $\mathrm{Y} 34^{\circ} 2^{\prime} 38 \mathrm{~N} X-5^{\circ} 2^{\prime} 57^{\prime \prime} \mathrm{W}$ \\
\hline Station 2 & Y34 $4^{\circ} 2^{\prime} 53 \mathrm{~N} X-5^{\circ} 1^{\prime} 1^{\prime \prime} \mathrm{W}$ \\
\hline Station 3 & $\mathrm{Y}^{\prime} 4^{\circ} 3^{\prime} 28 \mathrm{~N} X-4^{\circ} 59^{\prime} 16^{\prime \prime} \mathrm{W}$ \\
\hline Station 4 & $\mathrm{Y}^{3} 4^{\circ} 3^{\prime} 39 \mathrm{~N} X-4^{\circ} 56^{\prime} 43^{\prime \prime} \mathrm{W}$ \\
\hline
\end{tabular}

$\mathrm{pH}$, electrical conductivity and dissolved oxygen were conducted in situ; Then, the collected samples were transported to the laboratory and kept in an isothermal chamber at $4{ }^{\circ} \mathrm{C}$ to carry out the physico-chemical and microbiological analyses, according to Rodier's recommendations [Rodier, 2009].

\section{Analysis methods used}

\section{In situ analyses}

In the field, measurements of temperature, $\mathrm{pH}$, dissolved oxygen and electrical conductivity were carried out using a CONSORT Model C535 Multi-parameter analyser (Table 2).

\section{Analyses performed in the laboratory}

Regarding organic pollution parameters, the chemical oxygen demand (COD) was determined by oxidation of oxidizable materials in an acidic medium using an excess of potassium dichromate at a temperature of $150{ }^{\circ} \mathrm{C}$ in the presence of silver sulphate as a catalyst and mercury sulphate, which reduces the interference caused by the presence of chloride ion. The enumeration of faecal coliforms, streptococci and staphylococci was carried out by the most probable number (MPN) method (Table 3). The treatment of the samples by the physicochemical process was carried out by means of the Jar-test system type VELP SCIENTIFICA (JLT6).

\section{Statistical analysis}

The data collected was processed using EXCEL software to obtain arithmetic means and related standard deviations.

\section{Physicochemical treatment}

The preparation of the chemical coagulant was carried out by solubilising $20 \mathrm{~g}$ of the lime powder $\mathrm{Ca}(\mathrm{OH})_{2}$ in a litre of distilled water and to determine the optimal dose which shows the effectiveness of lime in this type of treatment. The prickly pear cactus (Opuntia ficus-indica) was washed, dried in an oven $\left(38^{\circ} \mathrm{C}\right)$ for 6 days, then ground and sieved to achieve a fine powder.

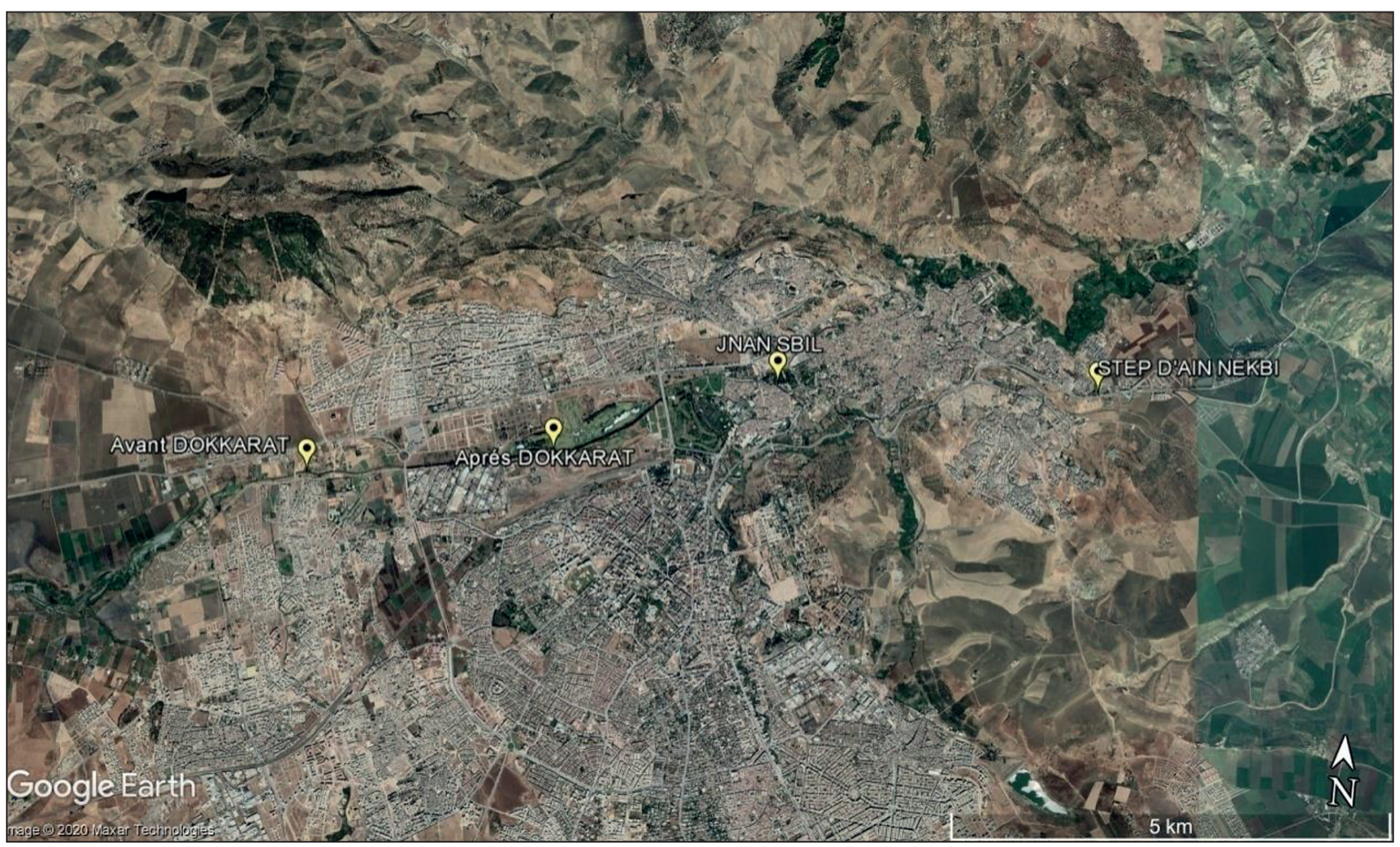

Figure 2. Map of stations on a satellite image background 
Table 2. Methods used for physicochemical analysis

\begin{tabular}{|c|c|c|}
\hline Parameters & Methods & Unit \\
\hline $\mathrm{pH}$ & \multirow{4}{*}{$\begin{array}{l}\text { Multi-parameter analyser Type CONSORT - } \\
\text { Model C535 }\end{array}$} & - \\
\hline Temperature & & $\mathrm{C}^{\circ}$ \\
\hline Conductivity & & Us /cm \\
\hline Dissolvedoxygen & & $\mathrm{mgd}^{\prime} \mathrm{O}_{2} / \mathrm{L}$ \\
\hline COD & $\begin{array}{l}\text { Hach lange LT200 thermostat for incubation } \\
\text { Spectrophotometer Hach lange DR } 3900\end{array}$ & $\mathrm{mgd}^{\prime} \mathrm{O}_{2} / \mathrm{L}$ \\
\hline
\end{tabular}

The jar-test experiment was conducted in a series of six $1 \mathrm{~L}$ beakers, $500 \mathrm{ml}$ of the raw effluent was introduced, the coagulant dose was varied to six values within a range of 3 and $20 \mathrm{~g} / \mathrm{Land}$ added into all beakers, the $\mathrm{pH}$ was adjusted according to the coagulant used. The mixture was subjected to a rapid stirring; then, doses of flocculant were added with slow stirring. Finally, the solution was transferred to a measuring cylinder and the mixture was allowed to settle.

\section{RESULTS AND DISCUSSION}

\section{Physicochemical and bacteriological quality}

\section{Physicochemical quality}

Figure 4 represents the variation of the parameters $\mathrm{pH}$, temperature, conductivity, dissolved oxygen, COD of the urban effluents of the city of Fez. The results obtained show that the parameters analysed vary significantly, according to time and space. These effluents are rich in suspended matter and are loaded in COD with the values that can exceed $1500 \mathrm{mg} \mathrm{O}_{2} / \mathrm{L}$.

- The $\mathrm{pH}$

The $\mathrm{pH}$ is between the maximum which is recorded in September (7.5), June (8.3), and the minimum which is recorded in December (5.5), February (5.8) in station 2 and 4 (Figure 4). The acidity is probably due in winter period to the olive industrial activities which discharge their liquid effluents(margins) directly into the receiving environment without any treatment this result agrees with that of Achak (2008), as well as with that of Bekri et al. (2021) and Zahari and al. (2014) and due to dissolved carbon dioxide coming either from the atmosphere or from metabolic reactions of microorganisms and organic matter contained in these waters, as mentioned by Achak et al. (2014).

- The temperature

Water temperature is one of the important factors controlling almost all microbiological reactions in aquatic environments [Ahmed, 2017]. The maximum temperature $\left(31^{\circ} \mathrm{C}\right)$ was recorded during the dry season (June 2019) at site 2 and the minimum temperature $\left(16^{\circ} \mathrm{C}\right)$ was obtained during the rainy season (December 2019), this parameter does not show great variations between the stations. The obtained results are consistent with the work done by Chafia Hajji (2013).

- The electrical conductivity

The values of electrical conductivity found in stations 2 and $4(>2700 \mathrm{us} / \mathrm{cm})$, are higher than the values set by the standards in force, which indicate that these waters are very strongly mineralised. This salinity can be linked essentially to the discharge of washing water [Chafia Hajji, 2013].

\section{- Dissolved oxygen}

Dissolved oxygen is a good indicator of pollution and plays a key role in the decomposition of organic matter and the deterioration of aquatic life. The oxygen content determined for the months under consideration is between $2.3 \mathrm{mg} / \mathrm{L}$ and $5.02 \mathrm{mg} / \mathrm{L}$ for all the water samples analysed. The values obtained are comparable to those found elsewhere for the waters of the Menoua Basin (West Cameroon), which generally have the $\mathrm{O}_{2}$ dissolved between

Table 3. Microorganism identification methods used

\begin{tabular}{|l|c|c|c|c|}
\hline \multicolumn{1}{|c|}{ Microorganisms } & Culture medium & Sowingmethod & Incubation time & References \\
\hline Streptococcus & Slanetz & Spreading & $48 \mathrm{~h}$ à $37^{\circ} \mathrm{C}$ & ISO standard $7899-1: 1984$ \\
\hline Fecalcoliform & Tergitol+TTC & Spreading & $24 \mathrm{~h}$ à $44^{\circ} \mathrm{C}$ & AFNOR NFV standard 08-017 \\
\hline Staphylococcus & Baird parker & Spreading & $48 \mathrm{~h}$ à $37^{\circ} \mathrm{C}$ & ISO standard $6888-3: 2003$ \\
\hline
\end{tabular}



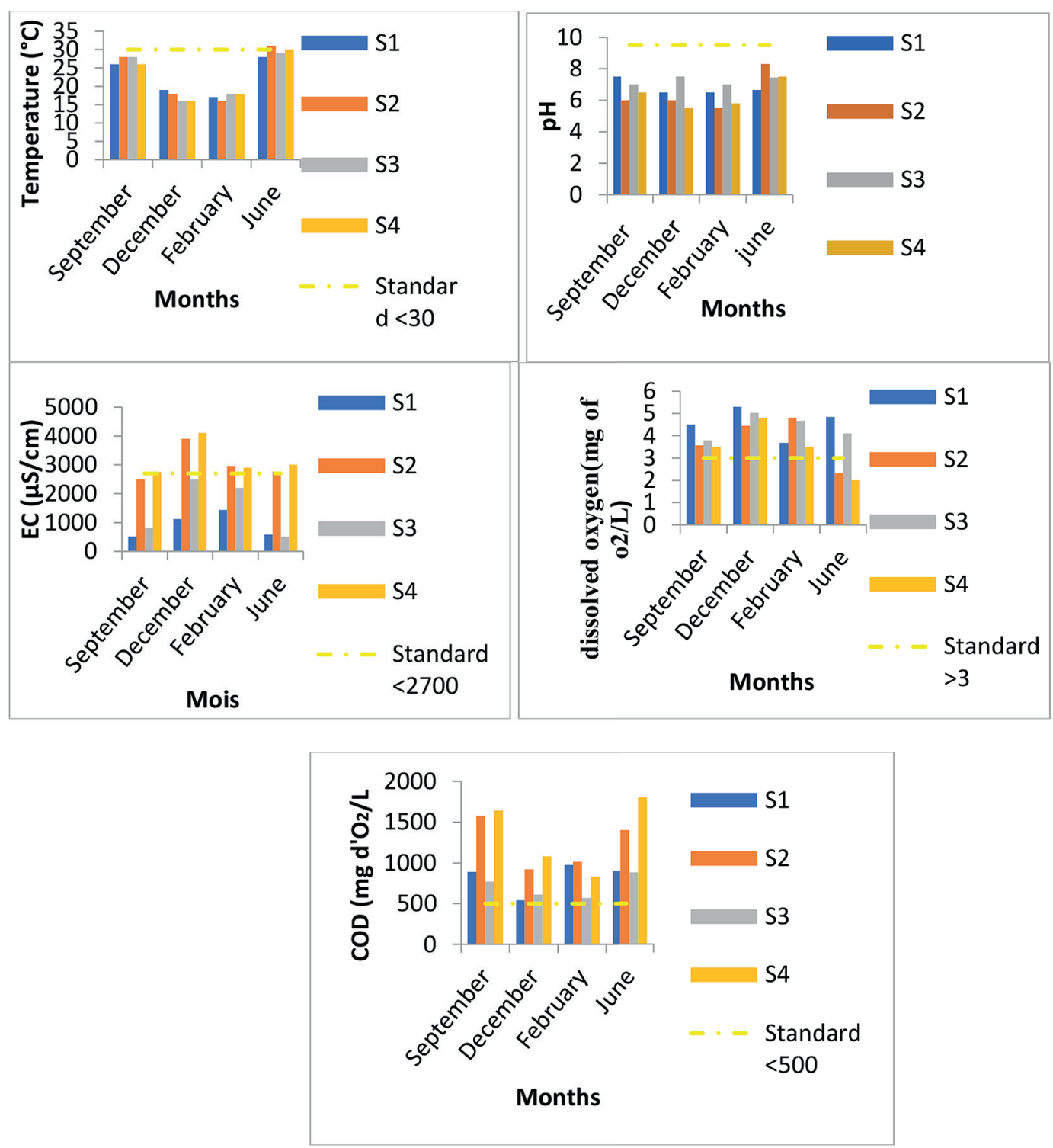

Figure 3. Spatio-temporal variation of physicochemical parameters of urban water in the city of Fez

$2.00 \mathrm{mg} / \mathrm{L}$ and $9.04 \mathrm{mg} / \mathrm{L}$ [Vital et al., 2018]. On the other hand, they are not different from those found in the raw wastewater of the city of Abidjan [Gnagne, 2015]. The low values of dissolved oxygen cause the development of pathogenic germs [Belghiti, 2013]. The variation of these dissolved $\mathrm{O}_{2}$ contents coincides with the increase and decrease of COD in urban waters, confirming the results presented in Figure 4. The low levels of dissolved oxygen may be due not only to the low water-atmosphere contact and the absence of plants capable of photosynthesis, but also to the possible infiltration of wastewater. Dissolved oxygen can be reduced by the activity of bacteria decomposing the organic matter present in the water [El Mouhri et al., 2021].

- The chemical oxygen demand
The chemical oxygen demand is very important for assessing water quality. It corresponds to the quantity of oxygen required for the degradation of organic matter or for their total chemical oxidation. The COD determination consists in chemically oxidising the organic and mineral matter contained in the water to be analysed by adding an oxidising agent: potassium dichromate $\mathrm{K}_{2} \mathrm{Cr}_{2} \mathrm{O}_{7}$ [Issi et al., 2019]. the waters studied have a high organic load in DCO, exceeding the norms for all the samples and which could be due to the discharges of industrial and craft activities, the study of El Mouhri et al. (2019) shows that heaverage concentration interms of COD in tannery wastewater from Fez city is about $11439 \mathrm{mg}$ $\mathrm{O}_{2} / \mathrm{L}$. Moreover, the values obtained in this study are comparable to those found by [Derwich et al., 


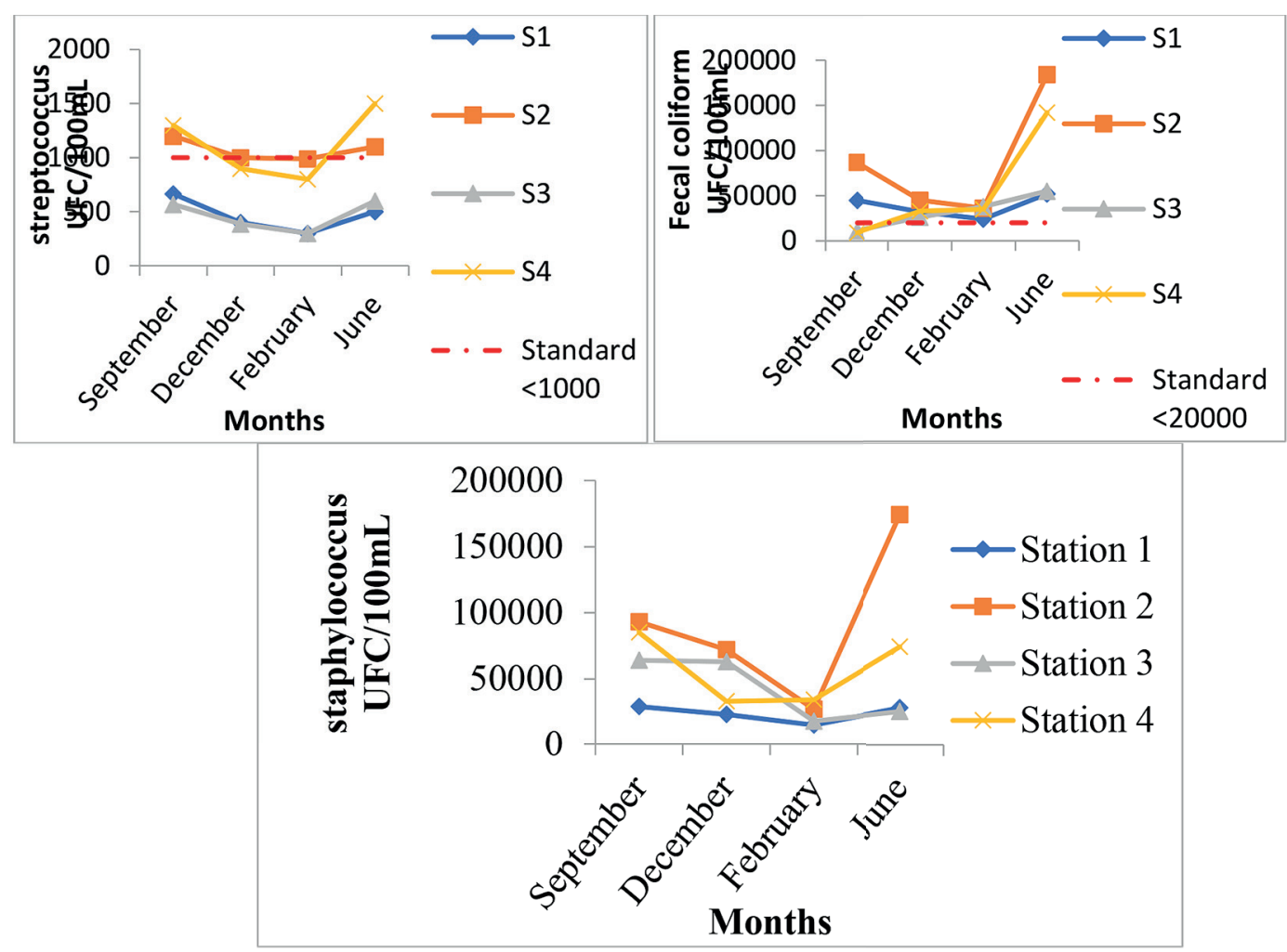

Figure 4. Spatial and temporal variation of microbiological parameters of urban water in Fez

2008]. This presents a sanitary threat and risks of water-borne diseases for the users of these waters [Abbou et al., 2018].

\section{The bacteriological quality}

The waters studied show average levels of germs indicative of contamination, with a difference from one site to another.

The results of the bacteriological analyses show that the waters studied are contaminated by faecal coliforms, streptococci and staphylococci. These indicate the pollution of faecal origin [Rodier, 1984]. The level of staphylococci and streptococci largely exceeds the Moroccan water standards in the course of the Fez river and more particularly in the waters of the sites located downstream of the city of Fez (Dokkarat and Ainnkbi), in June and September [Derwich et al., 2008]. While the faecal coliform (FC) load is well below the maximum value set by the standard in force, these results are in agreement with those found by Derwich et al. [2008], in the surface waters of the Fez river and Sebou used in market gardening.

\section{Contribution to wastewater treatment at the most polluted sites}

The tests were carried out on the most polluted waters, by coagulation flocculation, in order to identify the effectiveness of this treatment by the use of the cactus powder on urban waters aiming at a better effectiveness of the abatement of the organic compounds.

\section{Optimising the concentration of lime as a coagulant}

Figure 5 shows the effect of the concentration of lime coagulant on water treatment under welldefined operating conditions (at a stirring speed

Table 4. COD evolution during lime treatment

\begin{tabular}{|l|c|c|c|c|c|c|}
\hline Concentration $(\mathrm{g} / \mathrm{L})$ of lime $\mathrm{Ca}(\mathrm{OH})_{2}$ & 3 & 7 & 12 & 15 & 20 & 23 \\
\hline $\mathrm{pH}$ beforeadding coagulant & 8 & 8 & 8 & 8 & 8 & 8 \\
\hline $\mathrm{COD}$ before treatment $\left(\mathrm{mg} \mathrm{O}_{2} / \mathrm{L}\right)$ & 1800 & 1800 & 1800 & 1800 & 1800 & 1800 \\
\hline $\mathrm{COD}$ after treatment $\left(\mathrm{mg} \mathrm{O}_{2} / \mathrm{L}\right)$ & 1722 & 1455 & 1430 & 1260 & 1110 & 1200 \\
\hline $\mathrm{COD}$ abatement rate $(\%)$ & $4 \%$ & $19 \%$ & $20 \%$ & $30 \%$ & $38 \%$ & $33 \%$ \\
\hline
\end{tabular}


Table 5. Evolution of COD during water treatment by combining lime and cactus powder

\begin{tabular}{|l|c|c|c|c|c|c|}
\hline Concentration $(\mathrm{g} / \mathrm{L})$ of lime $\mathrm{Ca}(\mathrm{OH})_{2}$ & 20 & 20 & 20 & 20 & 20 & 20 \\
\hline Concentration $(\mathrm{g} / \mathrm{L})$ of cactus powder & 7.5 & 10 & 15 & 17.5 & 20 & 22 \\
\hline $\mathrm{pH}$ beforeadding coagulant & 8 & 8 & 8 & 8 & 8 & 8 \\
\hline $\mathrm{COD}$ before treatment $\left(\mathrm{mg} \mathrm{O}_{2} / \mathrm{L}\right)$ & 1800 & 1800 & 1800 & 1800 & 1800 & 1800 \\
\hline $\mathrm{COD}$ after treatment $\left(\mathrm{mg} \mathrm{O}_{2} / \mathrm{L}\right)$ & 946 & 830 & 749 & 767 & 770 & 800 \\
\hline $\mathrm{COD}$ abatement rate $(\%)$ & $47 \%$ & $53 \%$ & $58 \%$ & $57 \%$ & $57 \%$ & $55 \%$ \\
\hline
\end{tabular}

of $200 \mathrm{rpm}$ for $5 \mathrm{~min}$ for coagulation and $20 \mathrm{rpm}$ for $20 \mathrm{~min}$ for flocculation).

The results of Figure 5 shows that the chemical oxygen demand (COD) removal rate in the urban effluent increases along wih the lime dose, reaching a maximum value of $38 \%$ at alime concentration of $20 \mathrm{~g} / \mathrm{L}$. Beyond this value, a reversible effect is noticed.

\section{Optimising the concentration of the cactus powder}

After the urban water treatment trial with lime, treatment trials were carried out with the combination of lime and cactus powder (Opuntia ficusindi$\mathrm{ca}$ ) to find out the effect of the latter as a flocculant, with the fixing of process parameters and the variation of the concentration of Opuntia ficusindica powder from $7.5 \mathrm{~g} / \mathrm{L}$ to $22 \mathrm{~g} / \mathrm{L}$ (Figure 6).
The lime/powder combination is a very good alternative for treating liquid waste, with the production of a sludge consisting simply of biodegradable organic matter. The opuntia ficus indica powder has a very good flocculation capacity with lime, while avoiding toxicity to the environment and human health.The results show that there are two phases, an increase phase from $47 \%$ to $58 \%$ and a decrease phase of the abatement rate which could be explained by the inversion of the colloidal particles load. At a concentration of $15 \mathrm{~g} / \mathrm{L}$ a very good result was obtained, which is expressed by the increase in the COD abatement rate, reaching $58 \%$. The study carried out by Abid et al. (2010) for the treatment of chromium (VI) loaded effluents by the coagulation-flocculation process shows also that the combination of lime and coroboron cactus allows a reduction of $95.1 \%$.

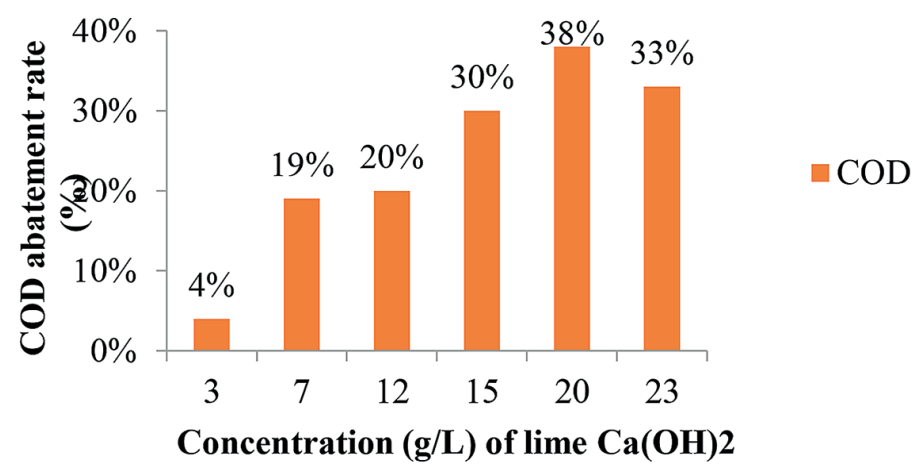

Figure 5. COD removal rate as a function of lime concentration

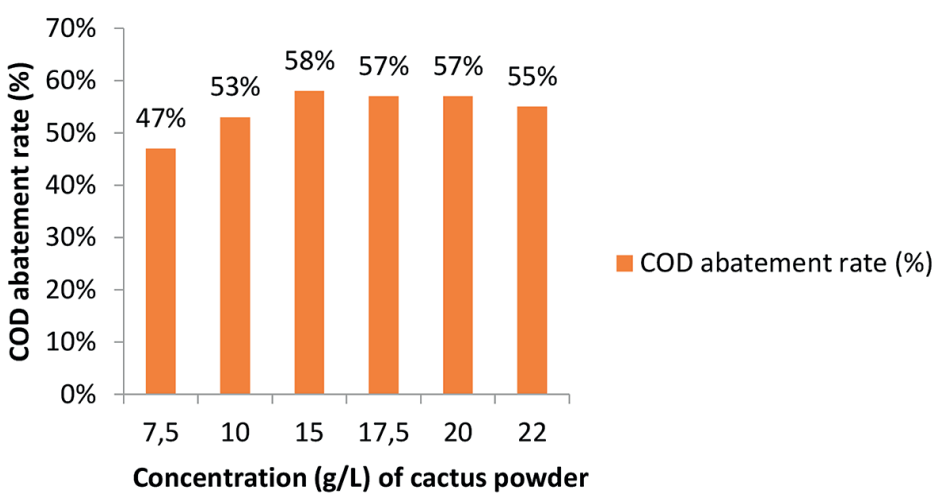

Figure 6. COD removal rate as a function of cactus powder concentration 


\section{CONCLUSIONS}

In conclusion, it can be said that the monitoring and the physicochemical characterization of the studied effluent shows that the latter constitutes one of the sources of contamination of Sebou river. Thus, a monitoring of these sources of pollution is thus necessary to validate a system of treatment. Taking into account these discharges loaded with organic matter, a physicochemical treatment based on coagulation-flocculation was presented, which has given satisfactory results in laboratory tests.

At the end of the evaluation of the organic pollution degree, it can be seen that this pollution is observable in two sites, by the acidic $\mathrm{pH}$, the low oxygenation of the water, the high COD value, and the very high contents of microorganisms translated by staphylococci, coliforms and streptococci. While the protection of these waters against various contaminations by the cactus cladode powder has numerous advantages, modifications to the physicochemical properties of the treated sample can be avoided and the recovered sludge will be biodegradable as well as free of iron or aluminium and chemical polymers. Cactus powder will therefore have a strong possibility to be an alternative to chemical flocculants.

\section{REFERENCES}

1. Abbou L., Bougarne M., Zemzami M.E., Haji L. 2018. Synthetic map of the quality of the surface waters of the Oued Inaouen watershed (Morocco), 322-328.

2. Abid A., Zouhri A., Ider A. 2010. Use of a new bioflocculant extracted from Moroccan cactus in the treatment of chromium (VI) loaded discharges by the coagulation-flocculation process. Afrique Sci. Rev. Int. Des Sci. Technol., 25-35.

3. Amarti-Riffi S. 2013. Managing the sewerage system of the city of fes, collecting, treating and valorising. Hte., 24-40.

4. Achak M., Ouazzani N., Yaacoubi A., Mandi L. 2008. Modern olive mill effluent characterization and their treatment by coagulation-flocculation using lime and aluminum sulfate. Modern olive mill effluent characterization and their treatment by coagulation-flocculation usi. J. Water Sci., 53-67.

5. Abbou M.B., Fadil F., El Haji M. 2014. Evaluation of the quality of the watercourses of the city of Taza used in the irrigation of market garden crops
(Morocco). J. Appl. Biosci., 77, 6462.

6. Ahmed A.A., Kit Y.W. 2017. MICIE: A Model for Identifying and Collecting Intrusion Evidences, Proc. 12th Int. Conf. Signal Image Technol. Internet-Based Syst. SITIS 2016, 288-294.

7. Bennouna A. 2020. Water management in Morocco and climate change. Rev. Espac. Géographique Société Marocaine, 250-259.

8. Belghiti M.L., Chahlaoui A., Bengoumi D. 2013. Study of the Physical and Chemical Quality of the Plio-Quaternary Table in the Meknes Region. Larhyss J., 21-36.

9. Bekri I., Taleb Z., Taleb S,. Tlemsani S., Hodaifa G., Belfedal A. 2021. High adsorption capacity of thermally treated solid olive wastes to treat olive mill wastewater.Environmental quality management, 0073.

10. Bzioui M. 2004. National Report on Water Resources in Morocco, UN Water-Africa, 94.

11. Chafia Hajji M.H., Bendou A. 2013. Characterization of liquid releases from a repair unit. International Journal of Heliotechnics, 29-36.

12. Derwich E., Beziane Z., Benaabidate L., Belghyti D. 2008. Evaluation of the quality of the surface waters of the wadis fes and sebou used in market gardening in Morocco, Larhyss, 59-77.

13. El Kharrassi Y. 2015. Highlighting the diversity of cactus (Opuntia spp.) populations in Morocco and the modulation of lipid metabolism by natural extracts and phytosterols from cactus or Argan oil in microglial cells, 221.

14. El Mouhri G., Merzouki M., Miyah Y., El Karrach K., Mejbar F., Elmountassir R., Lahrichi A. 2019. Valorization of two biological materials in the treatment of tannery effluents by filtration Treatment of tannery effluents by filtration. Moroccan J. Chem., 183-193.

15. El Mouhri G., Merzouki M., Kachkoul R. Belhassan H., Miyah Y., Amakdouf H., Elmountassir R., Lahrichi A. 2021. Fixed-bed adsorption of tannery wastewater pollutants using bottom ash: An optimized process. Surfaces and Interfaces, 22.

16. El Ouedghiri K., El Oualti A., El Ouchy M., Zerrouq F., Ouazzani Chahdi F., El Ouali Lalami A. 2014. Health risks related to chemical compounds contained in drinking water in the city of Fez: Case of nitrate and nitrite ions. J. Mater. Environ. Sci., 2284-2292.

17. Ferdaous L., Mohammed B., Bouderka Nouzha P., Hamid L., Abrerrahim L. 2015. Study of the physicochemical quality and metal contamination of surface water in the Beht Watershed (Morocco). Eur. Sci. J., 1111, 1857-7881.

18. Gnagne Y., Yapo B., Meite L., Kouame V., Gadji A., Mambo V., Houenou P. 2015. Physico-chemical and 
bacteriological characterisation of raw wastewater from the Abidjan sewer system. Int. J. Biol. Chem. Sci., 1082.

19. Issi A., Sema M., Segbeaya K.N. 2019. Impact of industrial wastewater discharge on the physico-chemical quality of urban waters: the case of the Kpiyimboua stream in Kara city Summary, 116-129.

20. Lalami O. 2011. Pollution of water from wells in some areas of the City of Fes Morocco, Rev. Microbiol. Ind. San Environn., 37-68.

21. Mohammed B., Mohamed J., Kamal A. 2017. Lithostratigraphic study of urban superficial formations in the northern sector of the City of Fez, Morocco. Eur. Sci. Journal, ESJ., 13, 129.

22. Rodier J., Legube B., Merle N. 2009. Water Analysis. 9th edition, DUNOD (Éditeur), Paris, Fr., 1600.

23. Vital S.N.C., Robert N., Benoît N.M. 2018. Pollution of water for human consumption and short-term health risks: The case of the Menoua River Basin (West Cameroon). Eur. Sci. Journal, ESJ., 14, 96.

24. Zahari A., Tazi A., Azzi M. 2014. Optimization of treatment conditions of Olive Oil Mill Wastewater by superoxidant K3FexMnyO8. J. Mater. Environ. Sci., 484-489. 